\title{
Current Risk Factors and Some Aspects of Prospective Development of Agro-Industrial Complex Potential in Tatarstan: Financial, Investment, Innovative
}

\author{
Akhmadeev M. G. ${ }^{1}$, Gerasimova O. E. ${ }^{2}$, Bagautdinova N. G. ${ }^{3} \&$ Arzhantseva N. V. ${ }^{1}$ \\ ${ }^{1}$ Kazan Institute (branch), "Russian Economic University" named after G.V. Plekhanov, Kazan, Russia \\ ${ }^{2}$ University of Management "TISBI”, Kazan, Russia \\ ${ }^{3}$ Kazan Federal University, Institute of Language, Kazan, Russia \\ Correspondence: Akhmadeev M. G., Kazan Institute (branch), "Russian Economic University" named after G.V. \\ Plekhanov, Kazan, 420111, Russia.
}

Received: March 10, 2015 Accepted: March 31, 2015 Online Published: April 30, 2015

doi:10.5539/ass.v11n11p206 URL: http://dx.doi.org/10.5539/ass.v11n11p206

\begin{abstract}
Aim: to define current risk factors and find out the ways to develop the agro-industrial complex potential in Tatarstan. Methods: in our research we have used the methods of synthesis, analysis and the method of management by objectives. Results: we have carried out the estimation of the influence of current risk factors on the development of agro-industrial complex in Tatarstan; we have given some recommendations on the choice of the ways how to improve its efficiency in modern conditions. Scientific novelty: we have found out and systematized key factors that influence the development of agro-industrial complex in modern conditions; we have described the principle on the basis of which the components are selected for the agro-industrial cluster with the estimation of their innovative potential taken as the ground for such research. Practical significance: having analyzed the key factors influencing the agro-industrial complex in modern conditions we have suggested the optimal current regional policy to develop and improve the agro-industrial potential in the Republic of Tatarstan.
\end{abstract}

\section{Introduction}

When Russian restrictions to import agricultural products from EU were introduced, there was observed a serious growth of opportunities for home producers to expand their market channels. This paper is devoted to the topical issues of how big their chances are to maximize their advantage and occupy the freed markets, to increase efficiency of the agro-industrial sphere, which will provide the long-term competition for them, and provide to the maximum the people of the country with the necessary volumes of agricultural products.

It is strategically important for the Russian government to work out an integral programme for the agro-industrial complex development in the current conditions. This programme should take into account all risk factors of its environment which will substantially increase its support. Such measures should be aimed at the decrease of dependence on production import and provide the development of non-resource sector in the country oriented on using the untapped capacity of regional agro-industrial complexes. This paper aims at finding out and estimating the key factors influencing the agro-industrial complex in Tatarstan and giving recommendations on the choice and realization of the optimal policy to increase its potential on the regional level.

\section{Results}

The agro-industrial complex of the Republic of Tatartan accommodates 4.5 mln hectares of farmland (3.4 mln of them are tillable soil), the proportion of which in the Russian Federation is $2.4 \%$, and the rural population comprises 931 thousand people.

According to the statistics issued by the Ministry of Agriculture and foodstuff of the Republic of Tatarstan the gross product of agricultural sector of Tatarstan made 150.1 billion rubles among all categories of households during 9 months of 2014, including crop production -61.5 billion rubles, cattle breeding -88.6 billion rubles, which exceeds the level of the analogous period of 2013 by $5.2 \%$ (at the comparable estimation). The expected 
levels for the year of 2014 in Tatarstan are the following ones: the agricultural gross product - 170 billion rub.; the production index $-102.0 \%$.

Marking the positive economic scenario for 2014 and talking about the long-term development prospects we can't but take into account one of the key non-controllable risk factors which is the weather conditions. The year of 2014 met quite favourable weather conditions and promoted growth of the gross production dynamics in agriculture. We should note the total agricultural scores of the previous 2013 year experiencing the lack of moisture which reflected the loss of positive development dynamics. The $2.2 \%$ decrease in 2013 compared to the level of 2012 was marked at the Final Board on the performance of the industry during the first year of realization of "Agricultural industry development through to 2020" programme on February 19th 2014.

We will mark the agricultural gross product dynamics in Tatarstan from 2008 to 2012 in Figure 1.

The diagram clearly shows a sharp index decline for extremely drought-impacted year of 2010, which emphasizes the objective existence of specific risk factors for agriculture and makes specialists think about the necessity to form a substantial stabilizing base which will allow to minimize the non-controlled risk effect.

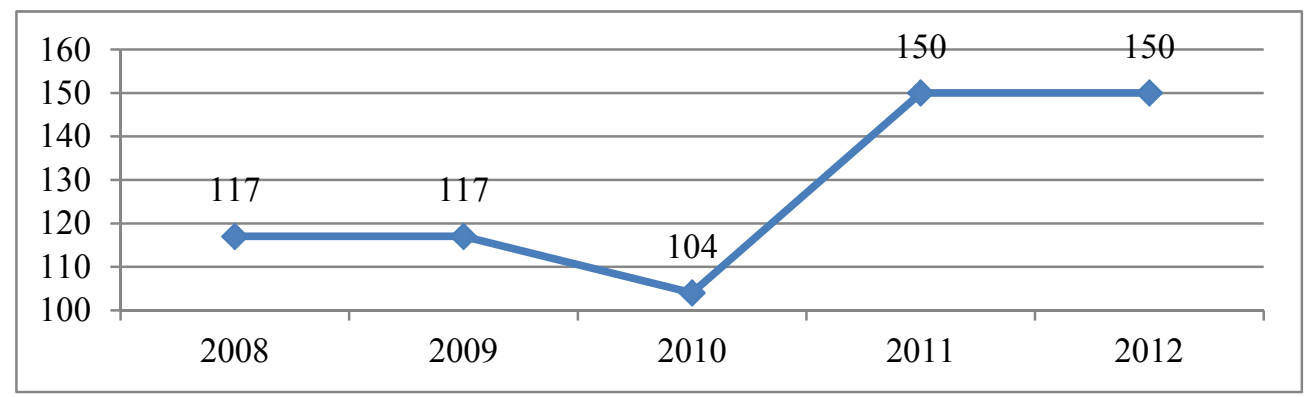

Figure 1. Agricultural gross product dynamics in Tatarstan 2008-2012 (billion rub.)

In the years of average climatic conditions the bearing point for supporting agriculture is the growth of the labour efficiency level which depends on such factors as energy- and technical capability of the industry as well as the effective labour management. The given circumstance determines the appropriateness of the efforts directed onto the intensification of usage of such instruments as additional financing, implementation and employment of both technological and managerial innovations into the sphere of agricultural business.

Let's mark the next risk factor. It is the economic situation in the country with the subsequent sufficiency of state financing allocated for the agro-industrial complex of Tatarstan and the prospects of investment revenues. We should mention the fact that in 2013 the Ministry of Agriculture of Russia stopped considering investment projects due to the absence of financing sources. Concerning the carried out investments, as is shown in Figure 2, the volume of investments into the agro-industrial complex in Tatarstan made more than 126.7 billion rubles for the period of 2008-2013.

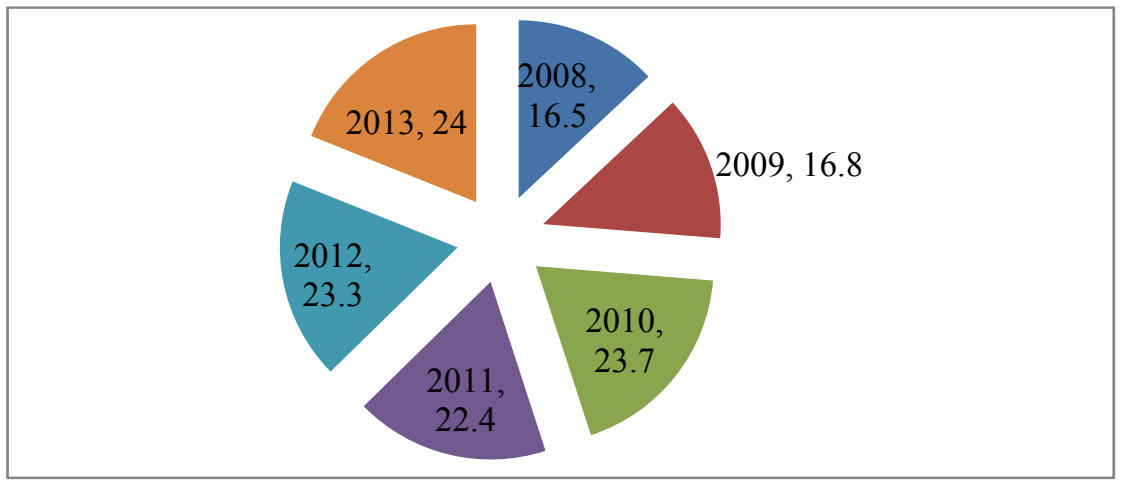

Figure 2. Volume of investments into the agro-industrial complex in Tatarstan for the period of 2008-2013 (billion rub.)

The statistics on October, 12014 shows that in Tatarstan the volume of subsidized bank credits in the framework of resources' provision of the agrarian project and the implementation of the State Programme for Agricultural 
Development and Agricultural Products, Raw Materials and Food Markets Regulation make 110.9 billion rub. for the period of $2013-2020,49.1$ billion rubles of which is investments.

The programme aims at "providing food supplies independence of Russia in the parameters set by the Food Security Doctrine of the Russian Federation ratified in the Russian Federation Presidential Decree № 120 on January, 30 2010; increase of competitiveness of Russian agricultural products on the international and home markets in the framework of Russia's accession into the World Trade Organization; increase of financial stability of the agro-industrial complex enterprises;

A steady growth of rural areas; reprocessing and efficiency increase of agricultural usage of land and other resources as well as the greening of enterprises."

The volume of budget allocations for the implementation of the Programme from the federal budget fund makes 1525586707.5 thousand rubles (in current prices) (Ministry of Agriculture of Russia - 1437819135.6 thousand rubles, Ministry of Culture of Russia - 2756432.4 thousand rubles, Federal Service for Veterinary and Phytosanitary Surveillance - 85011139.5 thousand rubles) (2014 N315).

In the framework of the given Programme we have made a forecast of the index dynamics for the growth of agricultural products production in households of all categories (in comparable prices), the diagram shows the percentage to the previous year in Tatarstan for 2013 - 2020 (Figure 3)

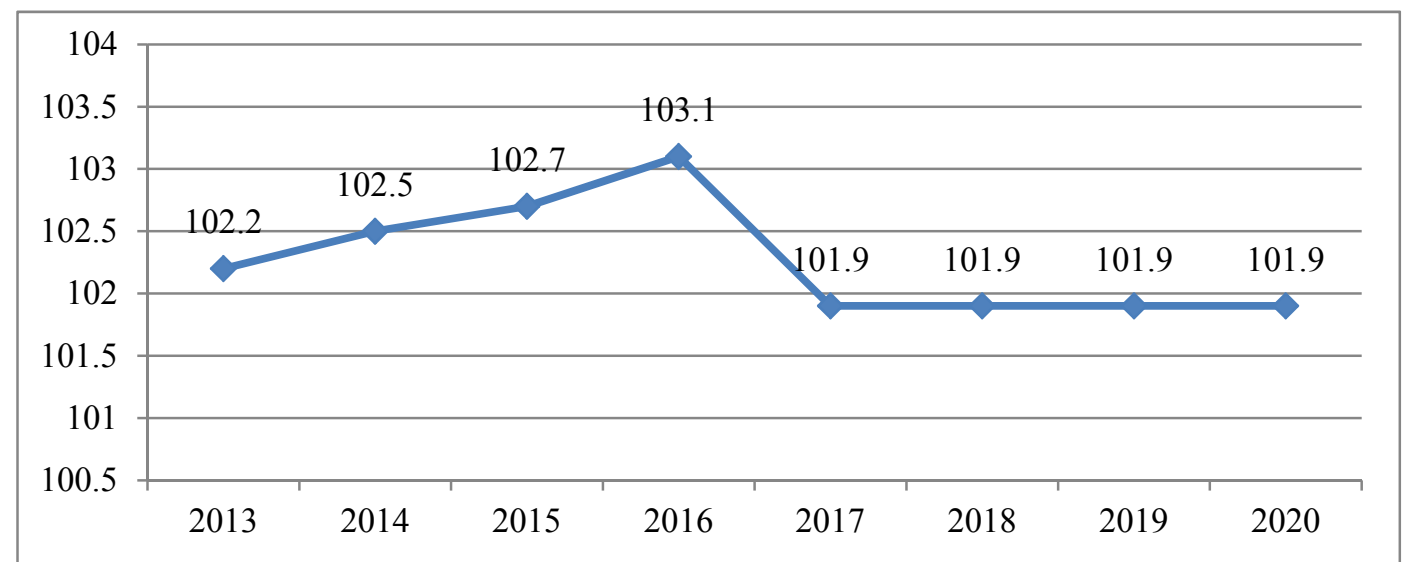

Figure 3. Agricultural products production index in households of all categories (in comparable prices), percentage to the previous year in Tatarstan according to pro forma data of State Programme for Agricultural Development and Agricultural Products, Raw Materials and Food Markets Regulation through to 2013 - 2020

As for other target programmes to support the agro-industrial complex functioning in Tatarstan we should mark the following ones: Leasing-grant 2014, the programme "Family cattle-breeding farms on the basis of farming enterprises in Tatarstan" through to 2012-2014, cattle-breeding and corn production farms development, the programme of Support for beginner-farmers through to 2012-2014, etc.

Besides those mentioned above, aiming at making bank credits more available for small business entities the Investment and Venture Fund of the Rebublic of Tatarstan together with the Committee on the small and middle-size business development and the Republican banks have worked out and implement programmes oriented to the creation and development of the projects in the real sector of economy in the following priority directions - expansion of production; acquisition and modernization of fixed assets; adoption of technology; innovative activity (http://base.garant.ru/).

Judging by the forecast and target setting the successful implementation of the given programmes of support could have a future chance for although not revolutionary but steady annual production growth of the branch, however, the fact remains that due to the policy of economic sanctions against Russia carried out by EU and the USA, the economic situation in Russia has been undergoing serious distress, and we can't exclude the risk of funding shortfall for the agro-industrial complex in Russia as well as in Tatarstan.

As we mentioned above the maintaining labour efficiency indexes by means of the technical equipment factor is treated as a key bearing point. Let us regard the statistical data on agricultural machinery renovation in Russia. Figure 4 shows the dynamics of coefficients of agricultural machinery renovation for 2000-2013. 


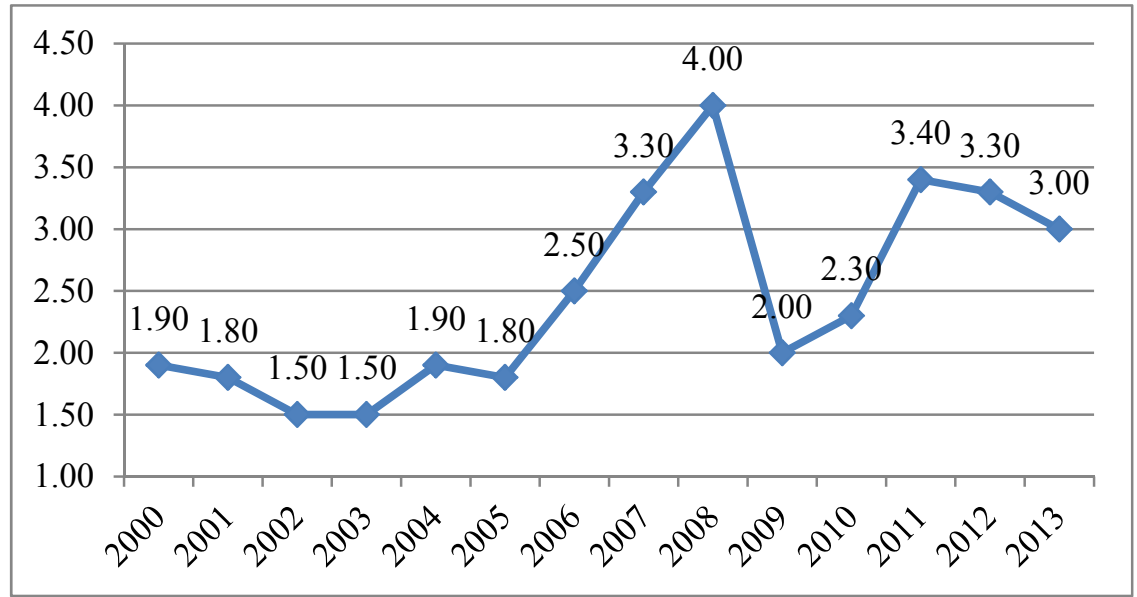

Figure 4. Coefficient of agricultural machinery (per cent) (tractors in general (without excavating, reclamation or other machines installed on them), Russia) (Kirshin, Datsyk, \& Titov, 2013)

It should be noted that the indexes are at low level and highlight the lack of financing for technical and technological modernization of the agro-industrial complexes in the Russian Federation, their maximum during 13 years doesn't exceed the level of 4.00 .

The prospectives of the development of the given direction include the following events in the framework of the Programme of technical and technological modernization for 2014-2016 (Table 1).

Table 1. Programme of technical and technological modernization for 2014-2016 (Glebova, Sadyrtdinov, \& Rodnyansky, 2013)

\begin{tabular}{|c|c|c|c|c|c|}
\hline \multirow{3}{*}{ Naming unit } & \multicolumn{4}{|c|}{ Years } & \multirow[t]{3}{*}{ Total } \\
\hline & \multicolumn{2}{|r|}{2014} & 2015 & 2016 & \\
\hline & forecast & fact August, 1 & & & \\
\hline \multicolumn{6}{|c|}{ Subsides from the budget of the Republic of Tatartan } \\
\hline Compensation of $40 \%$ value VAT excluded, billion rub. & 2,00 & & 2,00 & 2,00 & 6,00 \\
\hline \multicolumn{6}{|c|}{ Forecast for agricultural machinery acquisition } \\
\hline Tractors & 650 & 215 & 700 & 750 & 2100 \\
\hline Grain combine harvesters & 210 & 113 & 240 & 260 & 720 \\
\hline Forage combine harvesters & 60 & 75 & 70 & 80 & 210 \\
\hline Sowing machines & 60 & 34 & 70 & 80 & 210 \\
\hline Milking machines & 150 & 104 & 150 & 150 & 450 \\
\hline Mixer-feeders & 50 & 28 & 50 & 50 & 150 \\
\hline Milk cooling tanks & 150 & 61 & 150 & 150 & 450 \\
\hline Total, billion rub. & 5,8 & 3,9 & 5,8 & 5,8 & 17,4 \\
\hline Expected energy security & 164 & & 185 & 200 & \\
\hline
\end{tabular}

Energy security by January, $12014-158$ horsepower for 100 hectares

Judging by the forecast data the 3-year programme will allow to spend 6 billion rubles annually to acquire high-power multifunctional production machinery, which will increase the energy security up to 200 horsepower for 100 hectares of crop planting and will increase the labour efficiency twofold.

In the Republic of Tatarstan there is a plan to implement big investment projects in 2015 with the budget value of 2638 billion rubles at the production bases of the following enterprises of the agro-industrial complex of Tatarstan: JSC "Zainskii sakhar" (Zainsk sugar), JSC "Kulon Agro", JSC "Kamskaya Niva", CJSC "Nurlatskii sakhar" (Nurlat sugar), JSC "Greenhouse Center "Maiski"".

Investigating the innovative development factor as the factor of labour efficiency and competitiveness increase in the sphere of agro-industrial sector we are going to present and compare values and curve behaviour of the indexes of the share of innovative goods, works, services in the overall volume of shipped goods, performed works, services in the organizations of industrial production and service sphere all along the Russian Federation and the Republic of Tatartan (Figure 5 and 6). 


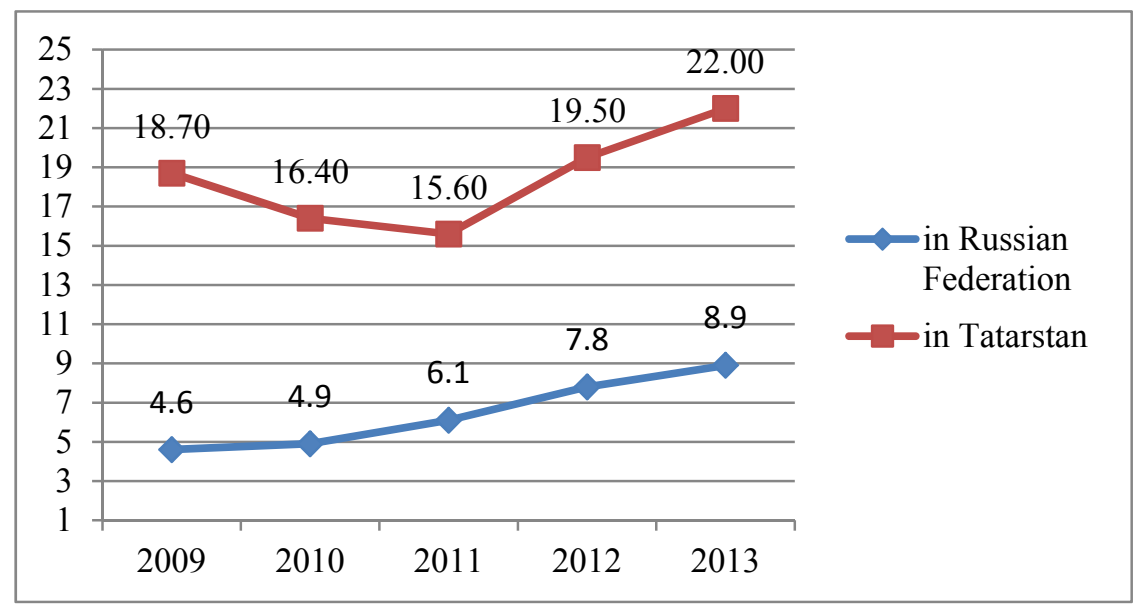

Figure 5. Share of innovative goods, works, services in the overall volume of shipped goods, performed works, services in the organizations of industrial production (Note 1) and service sphere, in the Russian Federation and Tatarstan.

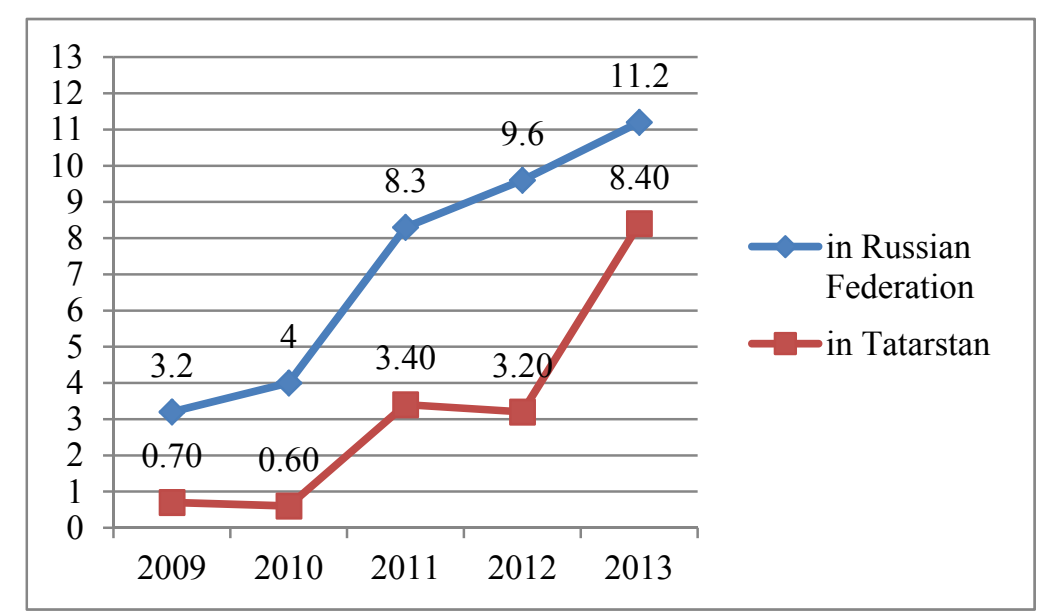

Figure 6. Share of innovative goods, works, services in the overall volume of shipped goods, performed works, services in the organizations of the service sphere, in the Russian Federation and Tatarstan

Judging by the curve behavior we might conclude that innovative potential is realized more effectively at industrial production enterprises of Tatarstan than in Russia in general, i.e. it exceeds the average index in Russia more than twofold, the share curve in both cases lies in the upward phase. The dynamics also grows at the service-rendering enterprises (the year of 2013 was marked by a confident leap from 3.2 to 8.4 in Tatarstan), however, the indexes here are more moderate than on average in Russia.

We will analyze the data of the innovative goods volume according to the types of economic activity in Russia (table 2), calculate the shares of innovative goods, works and services in their volumes in Russia. Since the curve behavior of the share of innovative goods, works and services in Tatarstan and Russia show similar tendencies we will use this fact and gross up the data obtained for Russia and give recommendations for Tatarstan.

It should be noted that besides agricultural sphere the agro-industrial complex includes the branches which ensure its effective functioning: machine-building; chemical, mineral and fertilizer production; process industries: food production, raw material processing for consumer goods industries; infrastructure: procurement, transportation, storage of agricultural products, delivering agricultural raw materials to the consumer, building and staff training for all spheres of the agro-industrial complex. Let us see the dynamics of the share in these types of activity (Figure 7).

We will single out economic activities arousing our outmost interest in the context of the innovative potential of the agro-industrial complex: tobacco and food production including drinks; chemical production; machinery and equipment production; scientific research and development. 


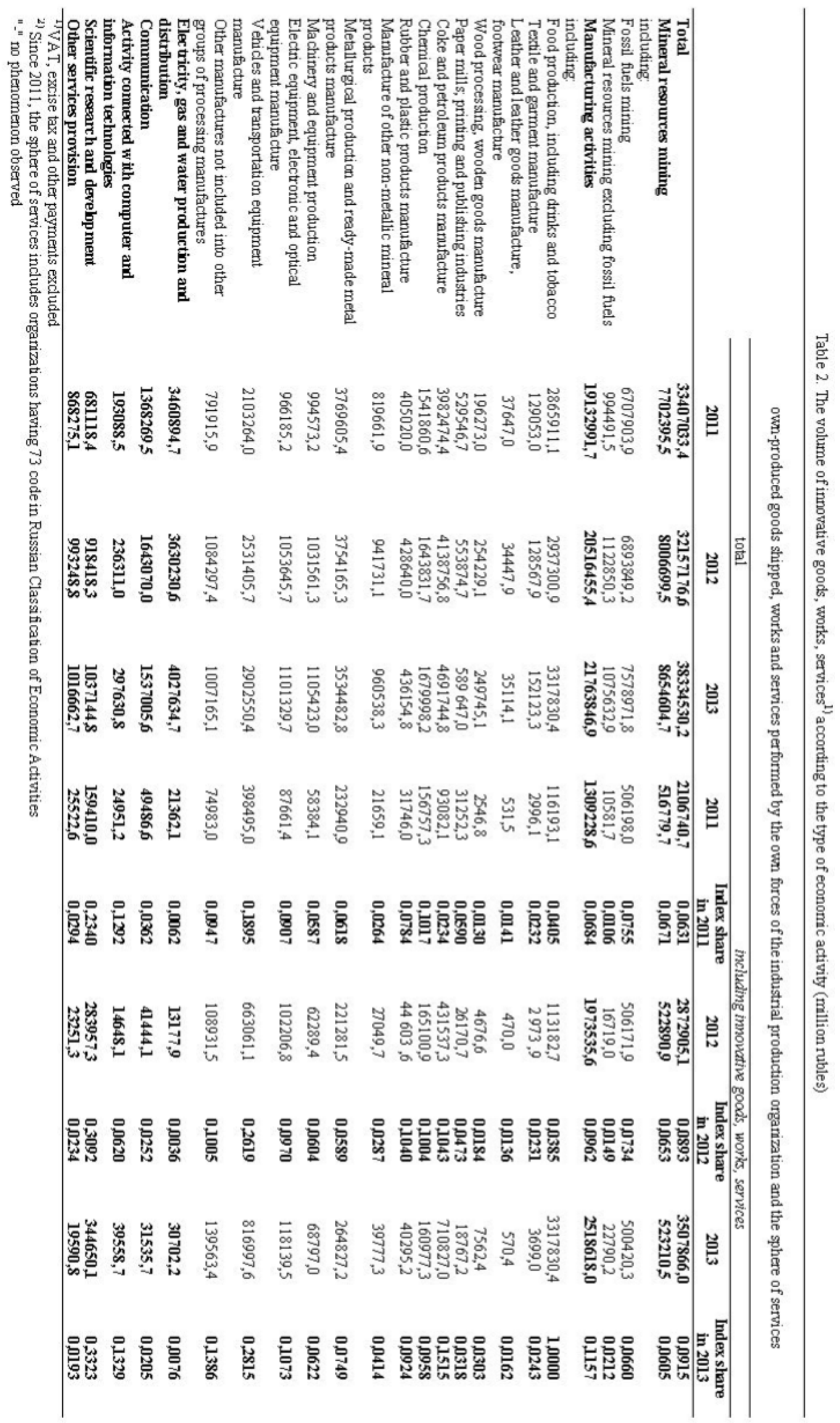




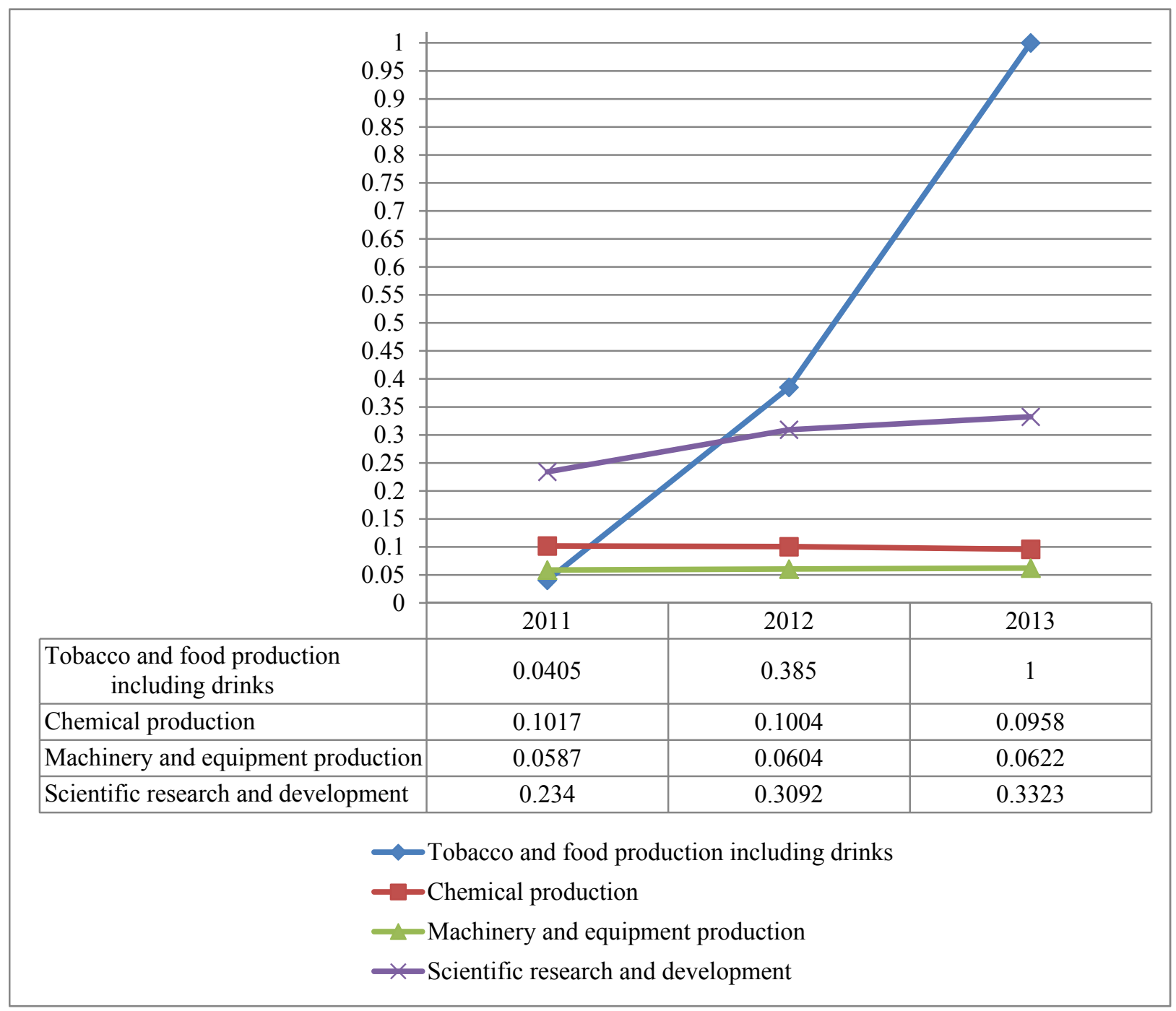

Figure 7

The highest innovative activity rates are observed in the sphere of tobacco and food production including drinks; it has lately reached the level of $100 \%$. The second place of the highest innovative activity rates is occupied by scientific research and development. The reason for their success, as our investigation has revealed, lies in the fact that those spheres experience rapid growth in the framework of cluster approach.

\section{Conclusions}

We have singled out a set of modern risk factors for the potential growth of the agro-industrial complex in Tatarstan, such as weather conditions; economic situation in the country with subsequent risks of insufficient state financing for the agro-industrial complex and investments curtailing; technical equipment of agriculture; innovative development factor.

In the light of current economic situation in the country there are no objective reasons to count for state financial and capital expenditure expansion, thus, it would be quite reasonable to turn to the issue of efficiency and competitiveness increase in the sphere of the agro-industrial complex in Tatarstan at the expense of economy acquired as the result of managerial innovations.

Taking into account the results of the carried out assessment of the agro-industrial complex development prospects in the context of those risk factors influencing it, we have come to the conclusion that the most prospective and reasonable regional policy for the potential development and empowerment of the agro-industrial complex of Tatarstan should be the implementation of cluster approach. 
Cluster approach could play a key role in this sphere, since regarding the forecast risks of insufficient financing for the agro-industrial complex it is the cluster development that could bring profit to Tatarstan enterprises. The projected profits could include efficiency increase at the expense of cost reduction in the given activity, development of the market, increase of flexibility and innovative potential while creating new products and technologies, which would substantially affect the potential growth of agro-industrial complex of Tatarstan in general.

\section{References}

Akhmadeev, M. G., \& Illarionov, M. G. (2012). The strategy of innovations management in the region on the basis of cluster approach (p. 188). Kazan: KI (f) RSTEU.

Annex N2 to the State Programme for Agricultural Development and Agricultural Products, Raw Materials and Food Markets Regulation through to 2013 - 2020 (the Governmental Decree edition July, 152014 N315)

Gerasimova, O. E. (2010). Formation of growing points as the instrument for space polarization management in the region (the example of the Republic of Tatarstan) (p. 116). Kazan: Publishing center Express format.

Glebova, I. S., Khabibrakhmanova, R., \& Yasnitskaya, Y. (2013). The Analysis of the Impact of the Investment Attractiveness Factors of the Region on the Fixed Capital Investments in the Economy of the Republic of Tatarstan. Middle-East Journal of Scientific Research, 17(10), 1498-1502.

Glebova, I. S., Sadyrtdinov, R., \& Rodnyansky, D. (2013). Impact Analysis of Investment Attractiveness of the Republic of Tatarstan on Fixed Investments of its Leading Companies. World Applied Sciences Journal, 26(7), 911-916, 2013.

Governmental Decree July 142012 N 717. State Programme for Agricultural Development and Agricultural Products, Raw Materials and Food Markets Regulation through to 2013 - 2020.

http://agk-invest.ru/programmi.aspx

http://agro.tatarstan.ru/

http://base.garant.ru/

http://programs.gov.ru/Portal/programs/list

http://www.aif.ru/money/economy/1136251

http://www.gks.ru

http://www.pravda.ru/news/economics/23-05-2014/1209226-hamidullin-0/

http://решение-верное.pф/family_farm

https://ru.wikipedia.org

Kirshin, I. A., Datsyk, A. A., \& Titov, A. V. (2013). Forecasting the Dynamics of an Innovative Cycle. World Applied Sciences Journal (Economics, Management and Finance), 27, 197-201.

Porter, M. (2007). Competitive strategy. The methodology of analysis of branches and competitors (p. 204). INFRA.

\section{Note}

Note 1. According to the form № 4 of Federal statistical surveillance - innovation "Data of the innovative activity of the organization" (annual). Starting from the report for 2011, the report comprises organizations with 73 code according to Russian classification of Economic Activities (Scientific research and investigations)

\section{Copyrights}

Copyright for this article is retained by the author(s), with first publication rights granted to the journal.

This is an open-access article distributed under the terms and conditions of the Creative Commons Attribution license (http://creativecommons.org/licenses/by/3.0/). 